\title{
Selenium (Se) supplementation on the Se status of dairy cows in the Midlands of KwaZulu-Natal
}

\author{
J.B.J. van Ryssen ${ }^{1}$ and E.D. O'Dell ${ }^{2}$ \\ ${ }^{1}$ Department of Animal \& Wildlife Sciences, University of Pretoria, 0002 Pretoria, South Africa \\ ${ }^{2}$ Summer Hill Stud, P.O. Box 313, Mooi River 3300, South Africa
}

\begin{abstract}
A dose-response trial was conducted with dairy cows on six farms in the Ixopo district of the Midlands of KwaZulu-Natal. Up to 30 cows per farm received a single subcutaneous injection of $5 \mathrm{~mL}$ of a long-acting/slow-releasing selenium (Se) supplement containing $50 \mathrm{~g}$ Se as barium selenate/mL (Deposel). The same number of matching cows per farm was used as controls. The cows grazed cultivated pastures and received concentrates containing no added Se. Whole blood Se concentrations were determined on day 1 and at $\mathrm{ca}$. three month intervals thereafter. The investigation was conducted for periods ranging from between 300 and 400 days on the different farms. Incidences of retained placenta, metritis, cystic ovaries, mastitis and calf mortality were recorded. Whole blood Se concentrations of the unsupplemented cows ranged from 17 to $90 \mathrm{ng} / \mathrm{mL}$. Accepting that a concentration of $>200 \mathrm{ng} / \mathrm{mL}$ blood indicates an adequate Se intake, the recorded concentrations suggest that the cows were deficient to marginally deficient in Se. The parenteral Se supplementation at the prescribed dose increased blood Se concentrations by an average of $32.8 \mathrm{ng} / \mathrm{mL}$, but this was insufficient to raise blood Se concentrations to adequate or recommended levels for dairy cows. No significant differences were recorded on the incidence of retained placenta, metritis, cystic ovaries, mastitis and calf mortality. It was concluded that, if not supplemented, dairy cows grazing cultivated pastures in the Ixopo district of KwaZulu-Natal are likely to be deficient to marginally deficient in Se. However, the prescribed dose of $5 \mathrm{~mL}$ of the slow-releasing Se supplement was too low to overcome the deficiency.
\end{abstract}

Keywords: Dairy cows, selenium, Ixopo, parenteral supplementation, Deposel

${ }^{\#}$ Corresponding author. E-mail: jvryssen@up.ac.za

\section{Introduction}

Soils in the high rainfall region of the Midlands of KwaZulu-Natal are classified as acidic, with a $\mathrm{pH}$ "frequently in the vicinity of 4" (Miles, 1991). These conditions are conducive to the occurrence of a selenium (Se) deficiency among grazing animals (Reid \& Hovarth, 1980). Higgins \& Fey (1993) recorded low concentrations of Se $(<0.03 \mathrm{mg} / \mathrm{kg} \mathrm{DM})$ in ryegrass from the Natal Midlands, suggesting that a Se deficiency is likely in animals grazing these pastures. Van Ryssen et al. (1992; 1999) conducted doseresponse trials on sheep in various regions of the Natal Midlands, and recorded growth responses in lambs grazing cultivated pastures upon receiving supplemental Se. The region is a prominent milk producing area predominantly from cultivated pastures which are irrigated when necessary. In a survey conducted among dairy herds in the Ixopo district of Natal, an area not covered in the investigations by Van Ryssen et al. (1992; 1999), O'Hagan (1994) found that the glutathione peroxidase activity in the erythrocytes of dairy cows indicated that cows in this region might be suffering from a Se deficiency. This prompted the current study to investigate the response to Se supplementation in dairy cows in terms of health related problems and changes in whole blood selenium concentrations.

\section{Materials and Methods}

Six dairy farms in the Ixopo district of KwaZulu-Natal with excellent recordkeeping and management practices, were selected. The number of cows (predominantly Friesland/Holsteins, in their second or later lactations) on each farm is given in Table 1. The cows were paired for level of production and stage of lactation and, within a pair, randomly allocated to a group receiving supplemental Se or an unsupplemented control. All cows selected were either in milk or in calf. On all farms, a few cows were withdrawn from the study for reasons not related to the investigation. Each cow in the treatment group received a single subcutaneous injection of $5 \mathrm{~mL}$ of a slow-releasing, long-acting Se supplement (Deposel, containing $50 \mathrm{~g}$ Se 
as barium selenate $/ \mathrm{mL}$, Rycovet, Scotland). The cows grazed cultivated pastures throughout the year and concentrates containing no added Se were fed separately. The farmers were not informed which cows were treated, and routine dairy farming practices were followed. Whole blood Se concentrations were determined from blood collected before the cows were injected (Day 1) and at ca. three month intervals for the duration of the study. The investigation lasted up to between 291 and 414 days on the different farms (Table 1). Blood was collected from the caudal artery into $10 \mathrm{~mL}$ heparinised vacutainer tubes. Whole blood Se concentrations were determined, using the fluorometric method of Koh \& Benson (1983). Analysis of variance using the package, Genstat (1993), was used to compare differences between treatments.

The incidences of some disorders often associated with depressed immune functions in the body were recorded, namely the occurrences of retained placenta, metritis, cystic ovaries, mastitis and calf mortality (Harrison et al., 1984; Jukola, 1993; Smith et al., 1997). A count analysis was performed on these data, using the $\chi^{2}$ method described by Clarke (1987).

Table 1 Duration of study on each farm and number of cows used on the different farms

\begin{tabular}{lccc}
\hline Location & Number of & \multicolumn{2}{c}{ Number of cows* } \\
\cline { 3 - 4 } of farm & days & Treated & Control \\
\hline Hella-Hella 1 & 414 & 29 & 30 \\
Umzimkulu 1 & 357 & 22 & 20 \\
Lufafa Road & 386 & 14 & 13 \\
Creighton & 291 & 27 & 26 \\
Hella-Hella 2 & 358 & 30 & 27 \\
Umzimkulu 2 & 334 & 27 & 26 \\
\hline
\end{tabular}

\section{Results and Discussion}

Blood Se concentrations of the cows at the onset of the study and of the untreated cows throughout the study ranged from 17 to $90 \mathrm{ng} / \mathrm{mL}$ (Table 2). A whole blood Se concentration of $200 \mathrm{ng} / \mathrm{mL}$ was proposed by Jukola et al. (1996) to be the target value to optimize udder health in dairy cows. Kincaid (1999) considered whole blood Se concentrations ranging between 60 and $200 \mathrm{ng} / \mathrm{mL}$ as marginally deficient. It could be concluded that, when not supplemented, dairy cows grazing cultivated pastures in the Ixopo district are likely to receive insufficient Se through their diets.

Table 2 Blood selenium (Se) concentrations at the beginning and end of the collection periods on different dairy farms

\begin{tabular}{lcccc}
\hline \multirow{2}{*}{$\begin{array}{c}\text { Location } \\
\text { of farm }\end{array}$} & \multicolumn{4}{c}{ Blood Se concentration (ng/mL) } \\
\cline { 2 - 5 } & \multicolumn{2}{c}{$\begin{array}{c}\text { First collection ( } \pm \text { s.e.) } \\
\text { Day 1 }\end{array}$} & Last collection* $( \pm$ s.e.) \\
\cline { 2 - 5 } & Treated & Control & Treated & Control \\
\hline Hella-Hella 1 & $36 \pm 2.5$ & $31 \pm 4.4$ & $59^{\mathrm{a}} \pm 4.6$ & $23^{\mathrm{b}} \pm 2.2$ \\
Umzimkulu 1 & $16 \pm 1.5$ & $17 \pm 1.0$ & $47^{\mathrm{a}} \pm 4.6$ & $21^{\mathrm{b}} \pm 1.8$ \\
Lufafa Road & $25 \pm 1.6$ & $19 \pm 2.0$ & $65^{\mathrm{a}} \pm 3.8$ & $26^{\mathrm{b}} \pm 4.0$ \\
Creighton & $53 \pm 5.6$ & $48 \pm 4.7$ & $78^{\mathrm{a}} \pm 10.3$ & $41^{\mathrm{b}} \pm 3.5$ \\
Hella-Hella 2 & $68 \pm 4.3$ & $75 \pm 4.5$ & $126^{\mathrm{a}} \pm 8.1$ & $90^{\mathrm{b}} \pm 9.6$ \\
Umzimkulu 2 & $61 \pm 4.9$ & $66 \pm 7.1$ & $76^{\mathrm{a}} \pm 6.1$ & $42^{\mathrm{b}} \pm 3.8$
\end{tabular}

\footnotetext{
* Day of last collection, as given in Table 1; s.e. - standard error

$\mathrm{a}-\mathrm{b}$ Within rows referring to last collection, differences were significant at $\mathrm{P}<0.01$
} 
Whole blood Se concentrations in the unsupplemented groups fluctuated throughout the study, and lowest concentrations were recorded mainly during mid winter to early spring. Although variations in soil types would contribute to such variation, the extent of liming of the soils by farmers has not been recorded, but could have contributed to these variations. Miles (1991) reported that liming of soils would increase the $\mathrm{pH}$ and in turn increase the absorption of Se by plants (Cary et al., 1967). No effect of stage of lactation on the Se concentrations in blood could be established due to too many uncontrollable variables.

The overall response in blood Se concentration to the parenteral supplementation of Se is presented in Figure 1. The $5 \mathrm{~mL}$ of Deposel injection increased blood Se concentration by an average of $32.8 \mathrm{ng} / \mathrm{mL}$. These elevated levels have been reached by the time the second blood collections were done, at $c a$. 90 days after the onset of the study. These elevated levels were maintained throughout the test periods of up to 414 days. This supported other investigations in which it was found that the product increased and maintained an elevated Se status in sheep for two breeding seasons (Øvernes et al., 1985) or 18 to 20 months (Van Ryssen et al., 1992). However, in the present study the $5 \mathrm{~mL}$ Deposel injection was not sufficient to improve the blood Se concentrations to levels indicating an adequate Se intake in dairy cows, viz. $>200 \mathrm{ng} / \mathrm{mL}$ (Jukola et al., 1996).

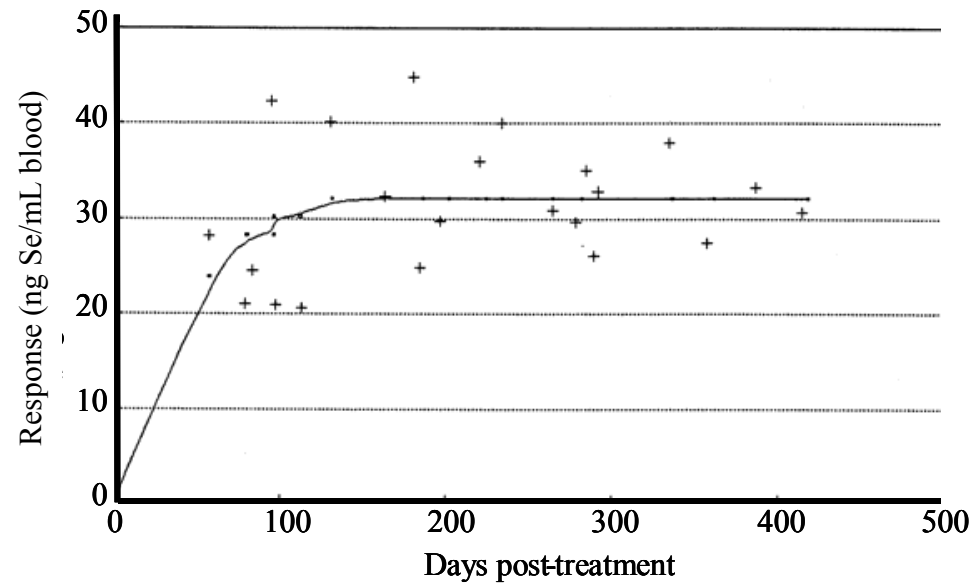

Figure 1 Response in whole blood selenium concentration above concentration in the respective unsupplemented groups on all six farms (Compertz equation: $\left.\mathrm{Y}=-475+508 \times \mathrm{e}^{(-\mathrm{e}(-0.0229 \mathrm{x}(\mathrm{X}+118)))}\right)$

Table 2 Incidences* (total for all herds) of parameters of animal health

\begin{tabular}{lccccc}
\hline & $\begin{array}{c}\text { Retained } \\
\text { placenta }\end{array}$ & Metritis & $\begin{array}{c}\text { Cystic } \\
\text { ovaries }\end{array}$ & Mastitis & $\begin{array}{c}\text { Calf } \\
\text { mortality }\end{array}$ \\
\hline Treated (n) & 9 & 17 & 0 & 18 & 7 \\
Control (n) & 9 & 20 & 6 & 23 & 19 \\
\hline
\end{tabular}

$\mathrm{n}$ - number of incidences recorded

* differences between treatments not significant

No significant differences were recorded between treatments in the measured parameters of animal health (Table 2). Considering that almost 300 cows were involved in the investigation, the incidences of these health problems were relatively low. That would limit the possibility of observing any health responses to Se supplementation. However, that could also suggest that most of the stimuli or challenges to the body that could trigger immune reactions in the cows, by responding to the supplementation of antioxidants such as Se, were minimal (McMurray et al., 1983). 


\section{Conclusion}

Selenium concentrations in the whole blood of dairy cows in the Ixopo district of KwaZulu-Natal indicated that cows grazing cultivated pasture could be suffering from a Se deficiency if they do not receive supplemental Se. However, the $5 \mathrm{~mL}$ Deposel injection was insufficient to elevate blood Se concentrations to levels considered to indicate a sufficient Se status. Although this could have contributed to the fact that no response was observed in health problems related to a Se deficiency, the incidences of retained placenta, metritis, cystic ovaries, mastitis and calf mortality even in the controls were too low to expect any dramatic response to supplementation. Further research is required to establish what level of supplementation with this product would be sufficient to elevate whole blood Se concentrations in dairy cows to a range considered adequate.

\section{References}

Cary, E.E., Wieczorek, G.A. \& Allaway, W.H., 1967. Reactions of selenite-Se added to soils that produce low Se forages. Soil Sci. Soc. Am., Proc. 31, 21-26.

Clarke, G.P.Y., 1987. Basic Statistics. Shuter \& Shooter (Pty) Ltd, Pietermaritzburg, RSA.

Genstat, 1993. Genstat 5. Committee of the Statistical Department, Lawes Agricultural Trust, Rothamsted, Oxford, Claredon Press, UK.

Harrison, J.H., Hancock, D.D. \& Conrad, H.R., 1984. Vitamin E and selenium for reproduction of the dairy cow. J. Dairy Sci. 67, 123-132.

Higgins, S.P. \& Fey, M.V., 1993. Selenium in some grass pastures of Natal and fertilizer-induced Se uptake by ryegrass (Lolium multiflorum). S. Afr. J. Plant Soil. 10, 188-192.

Jukola, E., 1993. Effect of selenium on the health of the dairy cow, with special reference to udder health and reproduction. Norw. J. Agric. Sci. Suppl. 11, 169-173.

Jukola, E., Hakkarainen, J., Saloniemi, H. \& Sankari, S., 1996. Blood selenium, vitamin E, vitamin A, and $\beta$ carotene concentrations and udder health, fertility treatments, and fertility. J. Dairy Sci. 79, 838-845.

Kincaid, R.L., 1999. Assessment of trace mineral status of ruminants: A review. Proc. Am. Soc. Anim. Sci. pp. 1-10.

Koh, T-S. \& Benson, T.H., 1983. Critical re-appraisal of the fluorometric method for determination of selenium in biological material. J. Assoc. Off. Anal. Chem. 66, 918-926.

McMurray, C.H., Rice, D.A. \& Kennedy, S., 1983. Nutritional myopathy in cattle; from a clinical problem to experimental models for studying selenium, vitamin $\mathrm{E}$ and polyunsaturated fatty acids interaction. In: Trace Elements in Animal Production and Veterinary Practice. Eds. Suttle, N.F., Gunn, R.G., Allen, W.M., Linklater, K.A. \& Weiner, G., Occ. Publ. No 7. Br. Soc. Anim. Prod., Edinburgh. pp. 61-73.

Miles, N., 1991. Nutrition of intensive pastures in the summer rainfall areas of southern Africa. J. Grassl. Soc. S. Afr. 8, 39-48.

O'Hagan, E.D., 1994. An investigation of selenium status of dairy cows in the Natal Midlands. MSc Agric. thesis, University of Natal, Pietermaritzburg, South Africa.

Øvernes, G., Moksnes, K. \& Frøslie, A., 1985. Barium selenate: A long-acting selenium preparation for subcutaneous injection. Acta Vet. Scand. 26, 164-168.

Reid, R.L. \& Hovarth, D.L., 1980. Soil chemistry and mineral problems in farm animals. A review. Anim. Feed Sci. Technol. 5, 95-167.

Smith, K.L., Hogan, J.S. \& Weiss, W.P., 1997. Dietary vitamin E and selenium affect mastitis and milk quality. J. Anim. Sci. 75, 1659-1665.

Van Ryssen, J.B.J., Bradfield, G.D., Van Malsen, S. \& De Villiers, J.F., 1992. Response to selenium supplementation of sheep grazing cultivated pastures in the Midlands of Natal. J. S. Afr. Vet. Assoc. 63, 148-155.

Van Ryssen, J.B.J., Coetzer, R.J. \& De Villiers, J.F., 1999. Supplementation of selenium to sheep grazing kikuyu or ryegrass: I. Selenium status of unsupplemented sheep and animal performance upon supplementation. S. Afr. J. Anim. Sci. 29, 137-144. 